\title{
Granica państwa jako kategoria wielowymiarowa
}

\author{
Grzegorz Balawajder ${ }^{1}$
}

\begin{abstract}
:
State border as a multidimensional category. The existence of state borders is mainly due to the assignment of territories to states as well as the territorial instinct typical for all human communities. The state border determines geographical territory and in this regard not only does it define the area of the state, but it also fulfils some specific functions that in their basic dimension are internal and external in character. The idea of a border cannot be related to the concept of a state border only. Border is a notion whose main scope concerns functioning of space. An important research problem is the issue of functions of borders. They can be analyzed from different points of view, for example: political and legal, military, economic, historical and cultural, linguistic, economic, ecological or sanitary and veterinary. As a result we can distinguish ten functions of borders: political and legal, of economy and customs, sanitary, historical, cultural, strategic, ideological, of limiting (measuring) peripherality, of legislative and other bodies arrangements and of contact area. All of these functions have one common denominator. It is the aspect of a barrier. We are witnessing an evolution of the functions of borders. With the development of integration processes we are moving away from the classical function of a barrier. Evolution of functions of borders also raises the question of the future of a nation-state.
\end{abstract}

Keywords:

border, national identity, border functions, typologies of borders, borderland' culture, integration process

Streszczenie:

Istnienie granic państwowych wynika przede wszystkim z przypisania państwom terytorium, a także z właściwego wspólnotom ludzkim instynktu terytorialności. Granica państwa, wyznaczając położenie geograficzne terytorium, określa nie tylko obszar państwa, ale spetnia również określone funkcje, które w podstawowym wymiarze maja charakter wewnętrzny i zewnętrzny. Mimo że na wielu obszarach granice zachowały tradycyjna funkcje bariery, wspótczesne granice nie funkcjonuja już w ten sam sposób, jak jeszcze $w$ niedalekiej przeszlości. W warunkach globalizacji kultury oraz internacjonalizacji polityki i gospodarki nastapilo otwarcie granic i zwiazane z tym ostabienie kontroli granicznej, stanowiacej dotychczas bariere dla przepływu ludzi, dóbr, kapitału i idei. Oznacza to, że wspótczesna percepcja granic państwowych dotyczy nie tylko zmian zachodzacych w obrębie instytucji państwa i jego polityk, ale również wiąze się ze zmianami w kontekśsie redefinicji obywatelstwa, suwerenności i tożsamości narodowej.

\section{Słowa kluczowe:}

granica, tożsamość narodowa, funkcje granic, typologie granic, kultura pogranicza, procesy integracyjne

Link do artykułu:

http://pogranicze.uni.opole.pl/biblioteka/docs/nr1/balawajder_nr1.pdf

Standard cytowania (APA):

Balawajder, G. (2013). Granica państwa jako kategoria wielowymiarowa. Pogranicze. Polish Borderlands Studies, $n r$ 1, s. 44-56.

Istnienie granic państwowych wynika przede wszystkim z przypisania państwom terytorium a także $\mathrm{z}$ właściwego wspólnotom ludzkim instynktu terytorialności, tj. dążenia do zapewnienia sobie wyłączności kontrolowania zdarzeń i procesów zachodzących na zamieszkiwanym przez nie obszarze (Jagielski 1995: 14). Granica państwa, wyznaczając położenie geograficzne terytorium, określa nie tylko obszar państwa, ale spełnia również określone funkcje, które w podstawowym wymiarze mają charakter wewnętrzny i zewnętrzny (Balawajder 2003: 229).

Wewnętrzny wymiar granicy państwa wyznaczony jest przez przestrzenny zasięg zwierzchności terytorialnej władzy i $\mathrm{w}$ tym względzie dotyczy regulacji i swobody działań podejmowanych przez różne grupy wewnątrz

1 Dr Grzegorz Balawajder: adiunkt w Katedrze Stosunków Międzynarodowych Uniwersytetu Opolskiego. 
państwa, migracji a także transferów finansowych i rzeczowych oraz przepływu informacji poza terytorium. Zatem granica $\mathrm{w}$ tym kontekście, wyznacza przestrzeń, w obrębie której państwo realizuje funkcje wynikające z posiadanej władzy. Z kolei zewnętrzny wymiar granicy dotyczy ograniczenia dostępu do terytorium państwa ze strony wszystkich podmiotów funkcjonujących poza jego obszarem.

Należy jednak zauważyć, że istoty granicy nie można wyłącznie odnosić do pojęcia granicy państwowej. Jak zauważa Heffner, badania nad istotą pojęcia granicy są prowadzone $\mathrm{w}$ wielu dziedzinach nauki i mają charakter interdyscyplinarny (Heffner 2010: 77). Ponadto, można również dostrzec wieloaspektowy wymiar przestrzenny granicy, ukazujący jej oddziaływanie w ujęciu globalnym, regionalnym, lokalnym i międzynarodowym, ale także dotyczący transgranicznych powiązań o ekonomicznym lub społeczno-kulturowym charakterze (tamże: 77 ).

Można zatem stwierdzić, że pojęcie „granica” posiada wiele różnych znaczeń, przy czym tylko część z nich ma znaczenie w sensie stricte geograficznym a więc dotyczącym funkcjonowania w przestrzeni. W znaczeniu etymologicznym (słownikowym) granica posiada bardziej ogólną definicję, odnoszącą się do linii zamykającej lub oddzielającej pewien określony obszar (kontur, zarys), lub dotyczącą pewnego ograniczonego zasięgu, miary, kresu czegoś dozwolonego (Szymczak 1991: 694). Stąd też w ujęciach słownikowych czy też leksykalnych pojęcie granicy jest często równoznaczne $\mathrm{z}$ takimi terminami jak brzeg, koniec, kres, linia podziału, limit, zakres czy zasięg.

W języku polskim pojęcie granicy jest używane w różnych kontekstach. Oznacza to, że ten termin może być wykorzystywany zarówno w odniesieniu do linii rozdzielającej państwa, jak również w innych kontekstach, dotyczących nie tylko innych podziałów terytorialnych w przestrzeni politycznej, czy też prawnej, ale również zjawisk zachodzących w przestrzeni kulturowej lub społecznej. Zatem ten sam termin używany jest w odniesieniu do granicy państwa czy też w odniesieniu do granicy jednostek fizyczno-geograficznych (np. granica na Brynicy rozdzielająca Górny Śląsk od Małopolski).
Z kolei w języku angielskim można spotkać znacznie bogatsze słownictwo odnoszące się do pojęcia „granica”. Tę kategorię pojęciową opisują takie terminy jak boundary, border, borderline oraz frontier (por. Batten 1999: 1-18). Jak podają $\mathrm{z}$ kolei Hastings Donnan oraz Thomas M. Wilson, termin border odnosi się do granic państwowych, frontier do obszarów stref przygranicznych, nadgranicznych i granicznych, natomiast boundary jest w tym względzie terminem najszerszym, ponieważ odnosząc się do granic społecznych zawiera w sobie charakter materialno-przestrzenny, oraz to, co szczególnie istotne dla jednostek i grup społecznych - wyobrażonych przez nie granic społecznych i symbolicznych. Ponadto, według tych autorów, dla określenia stanów przejściowych odnoszących się szczególnie do transformujących procesów społecznych, właściwym jest wprowadzenie kategorii liminal rozumianej jako liminalny (graniczny) (Donnan i Wilson 2007: 37; Grochalski 2010: 80). Z kolei John Robert Prescott w wydanej w latach osiemdziesiątych pracy Frontiers and Boundaries stwierdził, że granice (boundaries) są liniami, które wyznaczają terytorium państwa i w większości miejsc wyparły obszary graniczne (frontiers). Natomiast obszary graniczne były strefami o różnej szerokości i oznaczały zarówno polityczny podział między dwoma krajami, jak i podział między zamieszkałymi i bezludnymi obszarami wewnątrz państwa. Według Prescotta, nie można usprawiedliwić geografów, którzy używają terminów „obszar graniczny” (frontier) i „granica” (boundary) jako synonimów (Prescott 1987: 36). Autor wprowadził definicję granicy państwowej (border) twierdząc, że są to obszary przylegające do granicy (boundary), które je oskrzydlają, a pogranicza (borderlands) to strefy przejściowe, w obrębie których leżą granice (boundary) (tamże: 12-14).

Również w języku francuskim stosuje się różne terminy dla określenia granicy w sensie geograficznym. Jak podaje wybitny geograf francuski Jacques Ancel, mamy tutaj określenia limite, frontiere, borne, demarcation, charniere, seuil (Ancel 1938). Należy w tym miejscu zauważyć, że to właśnie nomenklatura francuska stanowiła pierwotny wkład w rozwój terminologii dotyczącej granic. Etymologia 
terminu granica wywodzi się od francuskiego frontiere co oznaczało linie frontu czy też frontonu (przyczółku) - a więc mamy tutaj do czynienia z pojęciem militarnym. Ale, jak podaje André Louis Sanguin, przez długi czas nie posługiwano się terminem frontier tylko limite - a więc „kres”. W tym względzie nawiązano do rzymskiego limes - pasa o długości $9000 \mathrm{~km}$, który miał chronić poprzez wykorzystanie muru, wież, kontroli przepływu ludzi i towarów. $Z$ kolei termin frontiere przyjęto jako efekt konstrukcji narodu. Było to ściśle związane z powstaniem państwa narodowego, którego funkcjonowanie było związane $\mathrm{z}$ atrybutem terytorialności. Terytorium wyznaczone było przez granicę linearną (limite), ale wymagającą ochrony i obrony, a więc wiążącą się ze służbą wojskową. Stąd pojawiło się pojęcie frontiere czyli linia frontu (strefa obrony) (Sanguin 1983: 1-10).

Z punktu widzenia rozważań prowadzonych w niniejszym tekście, wśród przedstawionych wielu określeń dotyczących granicy, najbardziej właściwym wydaje się termin border, ponieważ niewątpliwie wśród pojęcia granic najważniejsze znaczenie posiada granica państwowa. To ona wyznacza obszar zwierzchności terytorialnej państwa i zakres przestrzennego władztwa. Nadając państwu atrybut terytorialności i suwerenności odgrywa istotną rolę w postrzeganiu państwa jako najważniejszego uczestnika stosunków międzynarodowych. Wydaje się jednak koniecznym zwrócenie uwagi na fakt, że percepcja granicy państwowej, jako szczególnej kategorii, nie może pomijać funkcjonowania granic $\mathrm{w}$ innych aspektach dotyczących funkcjonowania przestrzeni.

W ujęciu przestrzennym, granicę definiuje się przede wszystkim, jako linię podziału pomiędzy obszarem o odmiennej przynależności politycznej, prawnej, administracyjnej, kulturowej, społecznej, instytucjonalnej, kompetencyjnej czy środowiskowej. Stąd też, jak stwierdza K. Heffner, granice W ujęciu geograficznym można analizować jako granice $\mathrm{w}$ przestrzeniach naturalnych, granice w przestrzeni kulturowej, granice w przestrzeni politycznej, granice obszarów planistycznych, granice w przestrzeni społecznej czy granice w przestrzeni społecznej. W przestrzeni geopolitycznej najważniejsze znaczenie posiada granica państwowa.
W literaturze spotykamy różne definicje granicy państwowej. Według Ludwika Ehrlicha granice państwa to $\mathrm{w}$ zasadzie linie geometryczne, a więc jednowymiarowe, w obrębie których mieści się obszar państwa (Ehrlich 1958: 507). Z kolei Alfons Klafkowski stwierdził, że pojęcie granicy państwa można określić zależnie od przyjętych kryteriów i w ten sposób konstatować, że:

1. granica państwa jest to linia, na której kończy się władza państwowa,

2. granica państwa jest to linia, która oddziela terytorium jednego państwa od terytorium innego państwa lub morza otwartego,

3. granica państwa jest to płaszczyzna prostopadła do powierzchni ziemi i ją przecinająca w kierunku geometrycznego środka ziemi; płaszczyzna ta oddziela obszary podlegające zwierzchnictwu terytorialnemu sąsiadujących państw - linia graniczna na powierzchni ziemi określa tylko sam przebieg granicy państwowej,

4. granica państwowa jest to linia zetknięcia się terytoriów dwóch państw (Klafkowski 1996: 116).

Z kolei Józef Barbag stwierdził, że istota granicy państwowej polega na tym, że określa ona zasięg terytorialnej zwierzchności poszczególnych państw i niedopuszczalność działania na tym terytorium władzy i praw drugiego państwa i że oddziela terytorium jednego państwa od innych państw lub też obszarów niepodlegających niczyjej suwerenności (Barbag 1987: 62). Inny polski geograf, specjalizujący się w geografii politycznej, Stanisław Otok stwierdza, że granica państwowa to powierzchnia prostopadła do powierzchni Ziemi, oddzielająca terytorium jednego państwa od terytoriów innych państw lub obszarów niemających niczyjej suwerenności, np. pełnego morza (Otok 2006: 77). Z kolei Zbigniew Rykiel definiuje granicę, jako linię podziału pomiędzy obszarami o odmiennej przynależności politycznej, administracyjnej, kulturowej, społecznej, instytucjonalnej, kompetencyjnej, środowiskowej lub innej, stanowiącej podstawę lub przyczynę rozróżnienia (por. Rykiel 2005).

Według Jacquesa Ancela, granica państwowa to koncepcja polityczna - ,izobara polityczna". Jej istota polega na tym, że granica państwowa wyznaczona, ustalona 
a nawet narzucona w wyniku negocjacji nie jest adekwatna do granic fizycznych, językowych czy też kulturowych, co powoduje, że staje się ona źródłem napięcia politycznego a także konfliktów (por. Ancel 1936). Natomiast amerykański geograf, Norman Pounds stwierdził, że granica państwowa to linia oddzielająca suwerenność danego państwa od suwerenności jego sąsiadów (Pounds 1936: 56).

Powyższe definicje traktują granicę państwową, jako podstawowy warunek istnienia terytorium państwa, a więc przestrzeni, w obrębie której państwo sprawuje swoją zwierzchność. Ponadto definicje te podkreślają polityczno-prawną rolę granic, jako kategorii wyznaczającej obszar, w obrębie którego państwo zachowuje swą suwerenność - tę cechę państwa, której integralną częścią jest zwierzchnictwo terytorialne.

Współczesna analiza istoty granicy państwowej pozwala stwierdzić, że kategoria ta stanowi rezultat dłuższego procesu rozwojowego. W starożytności, w okresie tworzenia się pierwszych struktur państwowych, granica państwa była wyznaczona przez pas graniczny, którego szerokość określały naturalne formy terenu, np. grzbiety górskie czy też rzeki. Ten pas graniczny pełnił wówczas dwie podstawowe funkcje: rozdzielał społeczeństwa oraz pełnił rolę linii obronnej. Wraz z rozwojem społeczeństw i ich naturalnym przemieszczaniem się, ten pas graniczny jako linia obronna zaczął przybierać kształt granicy politycznej linearnej. Rozwój państw powodował z kolei zacieśnienie pasów granicznych i ich ewolucję w stronę linii granicznych. Konsekwencją tych zmian było pojawienie się granic sztucznych. Proces ten widoczny był przede wszystkim tam, gdzie naturalne formy terenu nie sprzyjały ochronie terytorium państwa. Z kolei konsekwencją powstania granic sztucznych była ewolucja tej kategorii $\mathrm{w}$ kierunku tzw. linii (Balawajder 2006: 91).

Granica jako linia pojawiła się najwcześniej na obszarach najbardziej rozwiniętych gospodarczo a także gęściej zaludnionych. Wraz z rozwojem komunikacji a także kontaktów międzypaństwowych, nastąpiło zawężenie stref przygranicznych i zamiana ich w tzw. linie przygraniczne. To z kolei oznaczało przeniesienie granicy wyznaczonej na mapie (delimitacja) na rzeczywisty układ przestrzenny, a więc dokładne wyznaczenie przebiegu granicy w terenie (demarkacja). Należy w tym miejscu podkreślić, że podstawą ustalenia granicy państwowej oddzielającej dwa państwa od siebie jest umowa międzynarodowa, która oznacza zgodę obu państw na wyznaczenie i przebieg granicy w terenie. W umowie ustala się również tzw. strefę graniczną (2-6 km) lub szerszą strefę przygraniczną, w której najczęściej obowiązują rygory dotyczące ograniczenia w swobodzie przemieszczania się mieszkańców oraz kontrole ze strony służb państwowych. W celu ochrony granic ustanawia się pas drogi granicznej $(15 \mathrm{~m})$ oraz strefę nadgraniczną, co najmniej $15 \mathrm{~km}$ od granicy (por. Walters 2006: 187-203; Grochalski 2010: 107-108).

Jeżeli rozdzielenie terytoriów dwóch państw nie może nastąpić w wyniku podpisania umowy granicznej, to wówczas granica przyjmuje postać linii demarkacyjnej. Linie demarkacyjne pełnią funkcje granic państwowych tymczasowo i najczęściej wprowadza się je jako efekt zakończenia lub zawieszenia działań wojennych. Ich główną funkcją jest rozdzielenie stron konfliktu i wyznaczenie tymczasowej granicy, która najczęściej funkcjonuje jako linia rozejmu. Do najbardziej znanych linii demarkacyjnych, ustanowionych po 1945 roku należą:

- tzw. „zielona linia” między Izraelem, Jordanią i Egiptem po wojnie izraelskoarabskiej w 1948 roku,

- linia rozdzielająca Armenię i Azerbejdżan w obszarze Górnego Karabachu,

- siedemnasty równoleżnik w Wietnamie, rozdzielający Wietnam Północny i Południowy do momentu zjednoczenia w 1975 roku,

- trzydziesty ósmy równoleżnik rozdzielający dwa państwa koreańskie.

Rozwój historyczny granicy państwowej świadczy o tym, że nie jest to kategoria stała $\mathrm{w}$ czasie i linearna $\mathrm{w}$ formie (Jarczyński 2002: 62). Wraz $\mathrm{z}$ rozwojem państw a także postępujących przekształceń w obrębie struktur państwowych następuje ewolucja granicy, czego najbardziej widocznym przykładem są granice państw w obrębie struktur integracyjnych, takich jak np. Unia Europejska. W tradycyjnym, można powiedzieć 
klasycznym, układzie granica funkcjonuje jako bariera o bardzo słabej przepuszczalności, co powoduje, że obszary przygraniczne należą do kategorii obszarów peryferyjnych. Taka mało przepuszczalna granica nadaje tym obszarom charakter kresu państwa, pomimo, że obszar ten jest powiązany $\mathrm{z}$ układem regionalnym kraju (Rajman 1993: 221-230). Wraz z rozwojem procesów integracyjnych, stanowiących efekt przemian społeczno-gospodarczych owa bariera zaczyna zanikać, zwiększa się zakres przepuszczalności granicy i zanika jej charakter bariery przestrzennej.

Przykład wielu granic, a także dokonująca się ewolucja w zakresie ich funkcji pokazuje, że jeżeli granica funkcjonuje jako bariera (np. wynika to $\mathrm{z}$ rozdzielenia dwóch różnych pod względem systemu politycznego państw), to utrudnia to wymianę gospodarczą, kulturalną a także przemieszczanie się ludności. Zupełnie inny efekt daje zanik bariery spowodowany rozwojem procesów integracyjnych. Oznacza on zwiększenie przepuszczalności granic państwowych i osłabienie ich oddziaływania, jako przeszkody dla swobodnego przepływu ludzi, towarów i kapitału. Stopień przenikalności (przepustowości) granicy pozwala wyróżnić jej trzy główne kategorie:

- otwarte, odnoszące się do państw, które są już zintegrowane lub przechodzą przez ten proces $\mathrm{w}$ sposób zaawansowany, np. kraje oraz ich regiony przygraniczne $\mathrm{w}$ obszarze starej Unii Europejskiej,

- częściowo przenikalne, dotyczące państw rozwijających współpracę i stopniowo integrujących się, np. państwa i regiony w obrębie nowych członków Unii Europejskiej oraz sąsiadujące $\mathrm{z}$ nimi państwa i regiony $\mathrm{w}$ strefie zewnętrznych granic Unii,

- nieprzepuszczalne, dotyczące państw wykazujących tendencje izolacjonistyczne i brak otwartości na współpracę, np. podzielony Cypr czy też Korea (Martinez 1994: 1-15).

Ewolucja granicy spowodowała rozwój tej kategorii, czego szczególnym wyrazem jest typologia granic państwowych, pozwalająca klasyfikować granice według różnych kryteriów. Najbardziej klasycznym podziałem jest klasyfikacja uwzględniająca klasyczny podział na granice naturalne i sztuczne (Barbag 1987: 56).
Według J. Barbaga pojęcie granicy naturalnej obejmuje z jednej strony granice „wzięte z przyrody", z drugiej zaś dogodne do obrony. Granica naturalna, ze względu na przebieg może stanowić poważną przeszkodę dla migracji. Może też utrudniać przebieg szlaków komunikacyjnych. $Z$ kolei granice sztuczne to linie graniczne stricte narzucone lub ustalone przy stole konferencyjnym, w wyniku porozumienia pomiędzy sąsiadującymi państwami.

Inną klasyfikację granic przedstawił w latach 40-tych XX w. Samuel Whittemore Boggs. Wyróżnił on cztery typy granic:

1. granice fizyczne, ciągnące się wzdłuż naturalnej rzeźby terenu pod postacią łańcucha górskiego czy też rzeki,

2. granice geometryczne, mające postać linii prostych, wycinków łuku, koła, linii pokrywających się z przebiegiem współrzędnych geograficznych,

3. granice antropogeniczne, dotyczące różnorodnych cech osadnictwa i kultury ludzkiej, np. granice historyczne, językowe, kulturowe,

4. granice mieszane, czyli układ, w którym krzyżują się powyższe typy granic (por. Boggs 1940).

Należy zauważyć, że we współczesnej geografii politycznej klasyczny podział na granice naturalne i sztuczne nie ma pełnej akceptacji wśród geografów i często poddawany był krytyce (por. Rykiel 1990, Jędrzejczak 1997, Kałuski 1998). Jej meritum polegało przede wszystkim na zwróceniu uwagi na fakt, że rozróżnienie granic naturalnych i sztucznych ma zdecydowanie umowny charakter, ponieważ granice naturalne są wyznaczone w oparciu o wyraźnie widoczne w terenie linie lub obszary o genezie przyrodniczej, a więc łańcuchy górskie, rzeki czy też linię brzegową morza (Reynolds i McNutty 1968: 20-23). Jak zauważa K. Heffner, granice naturalne wywodzą się przede wszystkim z przyrodniczych zróżnicowań przestrzeni; z kolei granice sztuczne są konsekwencją zmian zachodzących w państwach, których zasięg określają, lub są efektem zewnętrznej presji innych państw (zmiany polityczno-ustrojowe prowadzące do rozpadu, wydzielenia się lub łączenia się państw i obszarów, konflikty wewnętrzne i zewnętrzne, działania zbrojne) (Heffner 2010: 88-89). 
Istnieje wiele przykładów pokazujących, że wyznaczone granice skupiają w sobie jednorodność cech przyrodniczych, jak i społeczno-gospodarczych, historycznych, kulturowych, narodowościowych sąsiadujących obszarów państwowych poprzez zbieżność przebiegu w wymiarze zarówno granicy naturalnej jak i sztucznej. W Europie takim przykładem może być granica hiszpańsko-francuska, portugalsko-hiszpańska czy też szwedzko-fińska. W przypadku granicy hiszpańsko-francuskiej mamy do czynienia $\mathrm{z}$ jednej strony $\mathrm{z}$ jej przebiegiem przez masyw Pirenejów, przy czym równocześnie ta naturalna granica dzieli dwa obszary pod względem językowym, kulturowym, gospodarczym czy nawet w pewnym sensie religijnym (konserwatywny Kościół katolicki w Hiszpanii i bardziej liberalny Kościół we Francji). Również granica hiszpańskoportugalska, wyznaczona w dużej części wzdłuż rzek Gwadiana, Tag i Duero, dzieli Półwysep Iberyjski na dwa różne pod względem językowym ale także kulturowym czy też gospodarczym obszary. Z kolei granica szwedzko-fińska, wyznaczona w dużej części wzdłuż rzek Torne i Muonio, również dzieli dwa obszary pod względem językowym, etnicznym i gospodarczym. Należy również zauważyć, że te naturalnie wyznaczone granice posiadają funkcję integrującą $\mathrm{i}$ stanowią wewnętrzne granice Unii Europejskiej.

Można zatem sądzić, że z punktu widzenia geografii politycznej z XIX wieku podział na granice naturalne i sztuczne wynikał przede wszystkim z założenia, że te granice, które nie były wytworem przyrody, były granicami sztucznymi. Ich funkcjonowanie było również związane $\mathrm{z}$ funkcją bariery, a więc miała ona charakter dezintegrujący. Jednak procesy integracyjne, które dokonały się w Europie Zachodniej od lat pięćdziesiątych XX wieku, doprowadziły do istotnej zmiany w zakresie myślenia o granicach. Stąd też współcześnie opracowywane typologie granic odchodzą od tego klasycznego podziału na rzecz podejścia zintegrowanego. Są to tzw. ujęcia genetyczne. W ujęciach genetycznych, najczęściej wyróżnia się cztery podstawowe koncepcje granic:

- granice sensu stricto, których podstawą są prawa natury,

- granice historyczne, oparte na argumentach wywodzonych z tradycji,
- granice „narodowe”, odpowiadające zasięgowi języka i rasy (koncepcja niemiecka),

- granice „narodowe”, oparte na zasięgu kultury (tamże).

Granice naturalne sensu stricto dotyczą takiej koncepcji granic, którą opisano na modelu fizyczno-geograficznym, uwzględniającym pasma górskie, rzeki, bagna, wododziały, uskoki, linię brzegową. Z kolei granice historyczne $\mathrm{i}$ narodowe, to $\mathrm{w}$ mniejszym lub większym stopniu wytwór człowieka, a więc posiadające typowo „sztuczny” charakter. Prowadzone w tym względzie rozważania podkreślają, że wszystkie granice polityczne, nawet przebiegające w oparciu o naturalne elementy środowiska przyrodniczego, są efektem ustaleń politycznych (umową społeczną) i w tym względzie stanowią wytwór człowieka a przede wszystkim państwa (Agnew 2001a: 7-26). Tam, gdzie przyjmuje się, że granice mają charakter naturalny, w praktyce zachodzi taka oto sytuacja, że warunki przyrodnicze zwykle pomagają człowiekowi w wyznaczeniu linii granicznej, stanowiąc $\mathrm{w}$ tym względzie określony punkt odniesienia (Agnew 2001b: 219-242). Taka granica jest zatem determinowana warunkami przyrodniczymi, co powoduje, że nie ma potrzeby jej szczegółowego wytyczania.

W typologii granic ważne miejsce zajmuje koncepcja Richarda Hartshorne'a, która stanowi niejako odniesienie do niejasności, wynikającej z dychotomicznego podziału na granice naturalne i sztuczne. Jeszcze w roku 1936, w warunkach toczonych już wówczas dyskusji na temat tego podziału, geograf ten zaproponował inny podział o charakterze genetycznym, w ramach którego wyróżnił cztery rodzaje granic:

1. granice antecedentne - ustanowione przed wykształceniem się środowiska socjokulturowego, np. granica USA - Kanada, ustanowiona w latach 1782-1786; Kanada - Alaska, po nabyciu Alaski przez USA, czy też granice państw w Ameryce Łacińskiej,

2. granice subsekwentne - ustanowione po wykształceniu się środowiska kulturowego, uwzględniające momenty historyczne, etniczne i gospodarcze, ale zgodne $z$ jego podziałem. Ten typ granic związany jest $\mathrm{z}$ powstaniem państw narodowych, przykładem mogą być państwa w Europie Zachodniej, 
3. granice narzucone - ustanowione po wykształceniu się środowiska socjokulturowego, ale nieuwzględniające jego podziałów. Przykładem mogą być granice nieuwzględniające podziałów etnicznych, narodowościowych czy religijnych, np. postkolonialne granice w Afryce i Azji,

4. granice reliktowe - utrzymujące się nadal $\mathrm{W}$ środowisku socjokulturowym, ale niepełniące już funkcji granic politycznych (Hartshorne 1936: 6-57).

Warto w tym miejscu zauważyć, że koncepcja R. Hartshorne'a stanowiła istotny wkład do dyskusji nad kategorią naturalności granic, szczególnie w okresie międzywojennym. Rozwój badań w zakresie geografii politycznej na przełomie XIX i XX wieku a także w kolejnych trzech dekadach XX wieku został zdominowany przez tzw. szkołę niemiecką, której głównymi reprezentantami byli Friedrich Ratzel oraz Karl Haushofer. Tworząc podstawy geopolityki, wprowadzili oni do geografii element organiczny, co spowodowało, że cała dyskusja nad problematyką ,naturalności" granic zaczęła mieć w coraz większym stopniu wymiar ideologiczny i służyć konkretnym celom politycznym (por. Pounds 1951).

R. Hartshorne również włączył się $\mathrm{w}$ tę dyskusję. W wydanym jeszcze w 1933 roku artykule „Geographic and Political Boundaries in Upper Silesia" odniósł się do kwestii granic wyznaczając pięć typów granic skupiających w sobie element środowiska przyrodniczego. Wskazane typy granic to:

1. granice naturalnie obronne,

2.granice wyznaczane przez przyrodę, zaznaczone od przyrody lub występujące (naznaczone) w przyrodzie,

3. granice chorograficzne lub granice strukturalne odnoszące się do obszarów krajobrazowo podobnych,

4. granice organiczne lub harmoniczne oznaczające zasięg obszarów zintegrowanych czy też silnie powiązanych gospodarczo,

5. granice krajobrazów kulturowych (por. Hartshorne 1932: 195-228).

Współczesne podejście do typologii granic skupia się przede wszystkim na trzech podstawowych grupach:

- granice polityczne: zmiany przebiegu granic, jako linii rozgraniczających organizmy państwowe,
- granice w polityce i w stosunkach międzynarodowych: nowe podejście do linii przestrzennego wymiaru zarządzania strukturami politycznymi, jako reakcja na procesy globalizacji,

- polityka tworzenia granic: tworzenie, ale też odtwarzanie granic $\mathrm{w}$ wymiarze przestrzennym, jako konsekwencja zmian w relacjach między narodami, państwami, terytoriami i tożsamościami (por. Paasi 1998: 69-82).

Inną ciekawą typologię proponują Liam O'Dowd i Thomas Wilson. Koncepcja tych autorów oparta jest na założeniu, że rozwój integracji w Europie służy rozwojowi współpracy transgranicznej. To właśnie $\mathrm{w}$ tych warunkach zachodzą nowe przesłanki funkcjonowania granicy. Stąd też autor wyróżnił cztery grupy funkcji granic politycznych: granice jako bariery, granice jako pomosty, granice jako zasoby, granice jako symbole tożsamości (por. O’Dowd i Wilson 1996: 1-19).

Druga połowa XX wieku przyniosła istotne zmiany na mapie politycznej świata. Były one związane przede wszystkim $\mathrm{z}$ rozpadem imperiów kolonialnych, który doprowadził do powstania nowych państw, głównie w Afryce i Azji. Towarzyszył temu proces wytyczania nowych granic, których delimitacja często była prowadzona $\mathrm{w}$ sposób sztuczny, nieuwzględniający rzeczywistych podziałów narodowościowych, etnicznych czy plemiennych. Ważną cezurą czasową dla tego okresu jest rok 1989. Upadek muru berlińskiego, najbardziej wyrazistego symbolu granicy pomiędzy dwoma światowymi blokami polityczno-militarnymi, oznaczał koniec zimnej wojny i wynikające z niego implikacje zmian na mapie politycznej świata. Dotyczyły one rozpadu imperium radzieckiego i w konsekwencji samego Związku Radzieckiego, a także powstania nowych państw w Europie i Azji. Dla mapy politycznej Europy ważne znaczenie miał rozpad Jugosławii i związana $z$ tym procesem seria etnonacjonalistycznych wojen. Zatem koniec XX wieku oznaczał istotny wzrost liczby państw na świecie. Obecnie społeczność międzynarodowa składa się z 203 państw, w tym ze 194 suwerennych, $\mathrm{z}$ powszechnym międzynarodowym uznaniem (193 państwa członkowskie ONZ i Stolica Apostolska jako stały obserwator). 
Pozostałe 10 państw to podmioty, które nie mają powszechnego uznania międzynarodowego: Autonomia Palestyńska, Kosowo, Arabska Demokratyczna Republika Sahrawi, Abchazja, Południowa Osetia, Turecka Republika Cypru Północnego, Naddniestrze, Górski Karabach, Somaliland oraz Republika Chińska (Tajwan) (Grochalski 2010: 103).

Wraz ze wzrostem liczby państw, zwiększyła się liczba granic między nimi. Spowodowało to nową styczność terytoriów i konieczność redefinicji struktury i funkcji ich granic. Z jednej strony owa nowa styczność oznaczała zwiększenie zakresu komunikacji i współpracy pomiędzy narodami i państwami. Z drugiej, mamy wiele przykładów, że przemiany po 1989 roku stały się źródłem nowych sporów granicznych. Można do nich zaliczyć konflikty pomiędzy państwami na tle postrzegania ich domniemanych, niepodległych terytoriów (np. między Armenią i Azerbejdżanem, Etiopią a Erytreą, Izraelem a Libanem, Grecją a Turcją, Serbią a Bośnią i Chorwacją), transgraniczne konflikty etniczne (Górny Karabach, Burundi i Ruanda, Grecja i Albania, Irlandia i Wielka Brytania, Palestyna i Izrael, Serbia i Albania), regionalne tendencje etnocentryczne i separatystyczne (wśród Czeczenów, Kurdów, Basków, Irlandczyków, Flamandów, Sikhów czy mieszkańców Quebecu) oraz lokalne, regionalne i narodowe działania, mające na celu wspieranie lub ograniczanie transgranicznych ruchów uchodźców i terrorystów (Donnan i Wilson 2007: 17-18). Dlatego też we współczesnym świecie, mimo tendencji integracyjnych, dostrzec możemy mury granice, które nadal dzielą państwa, narody. Do nich należą:

- posterunek policji w Belfaście,

- trzydziesty ósmy równoleżnik pomiędzy dwoma państwami koreańskimi,

- mur graniczny między Pakistanem a Indiami,

- mur dzielący Cypr na część grecką i turecką,

- mur rozgraniczający Izrael od Palestyny,

- mur między USA a Meksykiem,

- mur między Arabią Saudyjską a Jemenem,

- ,piaskowy”, pustynny mur między Marokiem a Mauretanią (Grochalski 2010: 21-22).
Powyższe przykłady pokazują, że współcześnie wiele rozgraniczeń między państwami ma charakter dyskusyjny, co nadaje granicom status granic spornych. Występują one zarówno na obszarach zamieszkanych, jak również na terenach słabo zaludnionych lub wręcz bezludnych. To powoduje, że obszarami o spornym charakterze są często strefy o niskiej wartości użytkowej (pustynie, bagna, lądolody). Istnienie granic spornych to najczęściej wynik niepokrywania się granic de facto i granic de iure. Pojęcia te oznaczają rozróżnienie faktycznego przebiegu linii granicznej w terenie od jej przeprowadzenia określonego prawem. W przebiegu większości współczesnych granic, granica de iure jest również granicą de facto. Jak stwierdza Stefan Marek Grochalski, istnieje jednak stosunkowo dużo stref konfliktów międzynarodowych, w których granice te nie pokrywają się, np. Izrael i Autonomia Palestyńska, Indie i Pakistan w prowincji Kaszmir, Chiny i Indie w prowincji Ladakh, Maroko i Sahara Zachodnia (tamże).

Mimo, że na wielu obszarach granice zachowały tradycyjną funkcję bariery, współczesne granice, w odniesieniu do dużej części państw, nie funkcjonują już w ten sam sposób, jak jeszcze w niedalekiej przeszłości. W warunkach globalizacji kultury oraz internacjonalizacji polityki i gospodarki nastąpiło otwarcie granic i związane $\mathrm{z}$ tym osłabienie kontroli granicznej, stanowiącej dotychczas barierę dla przepływu ludzi, dóbr, kapitału i idei. Ta nowa sytuacja stawia pytanie o przyszłość granic w kontekście przyszłości państwa narodowego (por. Balawajder 2010: 145-160). Jest ono uzasadnione, ponieważ zmiany funkcji granic pomiędzy państwami oznaczają poważne zmiany $\mathrm{w}$ sile i trwałości państwa narodowego a także w przebiegu procesów politycznych, gospodarczych i społecznych, które do tej pory postrzegano, jako wyraz wyłączności wynikającej z suwerenności państwa. Oznacza to, że współczesna percepcja granic państwowych dotyczy nie tylko zmian zachodzących w obrębie instytucji państwa i jego polityk, ale również wiąże się ze zmianami w kontekście redefinicji obywatelstwa, suwerenności i tożsamości narodowej. 
Granica państwowa, pomimo ewolucji w zakresie swoich funkcji, pozostaje istotną determinantą tożsamości narodowej. Taka konstatacja oparta jest na doświadczeniu, że bardzo wiele zjawisk dotyczących codziennego życia społeczeństw we współczesnym świecie dotyczy zdarzeń w strefach pogranicza. Wynika to przede wszystkim z funkcji, jakie pełnią granice w relacjach między państwami a także z faktu, że granice, w przeszłości, obecnie i w przyszłości, będą odgrywały znaczącą rolę $\mathrm{w}$ powstawaniu i rozwoju państw. Choć funkcje granicy podlegają ewolucji (por. Balawajder 2010a: 119-144; Balawajder2010b: 80,91-108), wiele cech przypisywanych granicom jest istotnych dla funkcjonowania narodów czy państw, zarówno w perspektywie historycznej jak i współcześnie. Granice mają bowiem swoje atrybuty, które odróżniają tę instytucję od innych obszarów w państwie. To powoduje, że ludzie żyjący w strefie pogranicza funkcjonują $\mathrm{w}$ nieco innych warunkach społecznych, ekonomicznych i politycznych niż pozostali mieszkańcy danego kraju. Jak stwierdził F. A. Adeyoyin, regiony przygraniczne jako systemy socjokulturowe są żyjącymi rzeczywistościami, które charakteryzuje wewnętrzna koherencja i jedność, te zaś są niezbędne z natury (Adeyoyin 1989). Z kolei wedhug Oscara Martineza, środowisko pogranicza charakteryzuje pięć istotnych procesów: transnacjonalizm, poczucie separacji i inności, strefa etnicznych konfliktów i akomodacji, strefa imigracji oraz miejsce międzynarodowych konfliktów i akomodacji (por. Martinez 1994: 8-14). Są one ze sobą ściśle skorelowane.

Transnacjonalizm to proces, który powoduje, że pogranicza funkcjonują pod wpływem życia społecznego rozwijającego się po obu stronach granicy. Wraz z upływem czasu ludność strefy pogranicza zaczyna przyjmować jako własne wartości, idee, zwyczaje oraz tradycje sąsiadów. Wynika to $\mathrm{z}$ jednej strony $\mathrm{z}$ peryferyjnego położenia $\mathrm{w}$ obrębie danego państwa, co w powiązaniu $\mathrm{z}$ ich lokalną kulturą i ekonomicznymi powiązaniami w wymiarze transgranicznym, wytwarza u miejscowej ludności poczucie politycznej i społecznej separacji i inności. Ponadto, granice są strefami etnicznych konfliktów i akomodacji wynikających przede wszystkim $\mathrm{z}$ powodu ich kulturowego zróżnicowania i znaczenia, jako strefy imigracji. Granice są też obszarem styczności w zakresie międzynarodowych konfliktów i akomodacji, co wynika $\mathrm{z}$ ich położenia oraz lokalizacji w ich obrębie określonych struktur $i$ agend państwowych.

Powyższe ujęcie granic pozwala traktować je zatem jako instytucje i procesy. Podobny pogląd wyraża Malcolm Anderson (Anderson 1996: 1-3). Według tego autora, granice, jako instytucje wyznaczają zakres suwerenności danego państwa oraz prawa poszczególnych obywateli. Z kolei, jako procesy realizują różne funkcje: są instrumentami polityki państwowej, stanowią wyznacznik tożsamości (według Andersona w XX wieku granice uczyniły z tożsamości narodowej pierwotną i najważniejszą tożsamość polityczną nowoczesnego państwa), są istotnym elementem w tworzeniu kultur narodowych. Jak podkreśla Anderson, to właśnie ta ważna zaleta granicy w procesie tworzenia i przetwarzania narodu i państwa, spowodowała, że granica państwowa staje się istotną kategorią w rozważaniach dotyczących narodowości i tożsamości.

Etniczność i tożsamość narodowa stanowią ważną determinantę funkcjonowania współczesnego państwa. Jeśli państwo jest jednolite $w$ tym wymiarze, stanowi to element jego wewnętrznej stabilności i w konsekwencji jego siłę. Jednak we współczesnym świecie w warunkach funkcjonowania państw narodowych bardzo trudno jest znaleźć państwo spełniające wymóg homogeniczności. Jak stwierdził Ilidio do Amaral, „nawet w Europie Zachodniej, miejscu narodzin idealnego, homogenicznego państwa narodowego, zróżnicowanie etniczne jest łatwe do zauważenia $w$ regionalnych i narodowych działaniach politycznych. Konflikty, które wyrastają z wieloetnicznego składu państwa, są najtrudniejszymi z tych, z którymi musi zmierzyć się rząd, i są na tyle poważne, że mogą nawet zagrozić integralności terytorialnej państwa" (do Amaral 1994: 17). Przykład Europy Zachodniej w kontekście zachodzących tam procesów dezintegracyjnych stanowi egzemplifikację zjawiska polegającego na tym, że etniczność i tożsamość narodowa stanowią współcześnie 
i będą stanowić w przyszłości realne zagrożenie dla wielu państw, analogicznie jak to miało miejsce w przeszłości.

W rozważaniach dotyczących funkcji granic w obszarze pogranicza dostrzec można zainteresowanie niektórych badaczy rolą kultury w kreowaniu i utrzymywaniu granic i stref przygranicznych, ze szczególnym zwróceniem uwagi na proces włączenia kultury do analiz tworzenia państwa na granicach, pomiędzy nimi i jako rezultat ich bytu (Donnan i Wilson 2007: 27). Tacy autorzy jak M. Anderson, L. O'Dowel, O. J. Martinez badali historyczną rolę lokalnych, regionalnych i narodowych kultur $\mathrm{w}$ procesie tworzenia i negocjowania granicy pomiędzy stanami Zjednoczonymi a Meksykiem oraz Francją i Hiszpanią. Autorzy ci stoją na stanowisku, że kultura jest kategorią niezwykle ważną dla badania międzypaństwowych granic. Wynika to przede wszystkim z faktu, że kultura jest czynnikiem determinującym dwustronne umowy graniczne, stanowiące podstawę delimitacji i demarkacji. Ta szczególna rola kultury wydaje się ważnym elementem składowym wielu rozmów dyplomatycznych, szczególnie, gdy prowadzone negocjacje dotyczą politycznych i ekonomicznych warunków na pograniczach. Ponadto, lokalne i regionalne kultury odgrywają istotną rolę, wpływając na proces kształtowania się polityki, jej artykułowanie i przyjęcie na granicach i poza nimi. Kwestia kultury na granicach jest też istotna $\mathrm{z}$ tego względu, że polityka państwowa, która służy współpracy dwóch sąsiadujących państw lub generuje $\mathrm{w}$ tym względzie konflikty, zawiera w sobie nie tylko aspekty ogólnopaństwowe, lecz również dotyczy funkcjonowania regionów i społeczności lokalnych, żyjących w układzie transgranicznym. Istotnym wydaje się również fakt, że wszystkie wspólnoty strefy pogranicza mają własne granice kulturowe, w obrębie których odbywa się mniej lub bardziej intensywny proces komunikacji i negocjacji.

To znaczenie kultury dla badania procesów przebiegających w obrębie społeczności międzypaństwowych pograniczy pozwoliło na wprowadzenie pojęcia kultury graniczne (tamże: 27-28). Funkcjonują one na dwóch zazębiających się i nierozłącznych poziomach. Kultura łączy ludzi i instytucje strefy pogranicza z ludźmi i instytucjami własnego państwa oraz instytucjami ponadnarodowymi, związanymi z przynależnością do określonych struktur integracyjnych. Te kultury graniczne generują sieci społeczne, które łączą ludzi z obszaru pogranicza $\mathrm{z}$ innymi jednostkami, obejmującymi tych, którzy w ramach podróżowania przekraczają granice oraz tych, którzy mają władzę w centrach państw, a ich decyzje wpływają na życie w strefie pogranicza. W tym kontekście istotne znaczenie mają również doświadczenia ludzi, dla których granica jest źródłem utrzymania. Ludzie żyjący w strefie pogranicza, poprzez swoją egzystencję, wyznaczają charakter kultur granicznych - ich styl życia, system wartości i sposób wzajemnego odnoszenia się, które ta społeczność podziela wyłącznie lub głównie z innymi pograniczami po tej samej lub drugiej stronie granicy. To powoduje, że lokalne granice kulturowe mają często wymiar szerszy niż granice państwowe. Narodowa kultura, funkcjonująca w założeniu w obszarze wyznaczonym przez granice państwowe, przenika przez lokalne granice kulturowe, niwelując $\mathrm{w}$ ten sposób instytucjonalne ograniczenia państwa. Obecnie coraz większa liczba ludzi doświadcza kontaktu z innymi osobami, korzystając ze swobody przekraczania granic, szczególnie w odniesieniu do rozwiniętych struktur integracyjnych, takich jak Unia Europejska. To spowodowało, że granice stały się obszarami kontaktu łączącymi transgraniczne wspólnoty. Tym samym granice międzypaństwowe stały się obszarami pogranicza, co przyczyniło się z kolei do przekształceń samych pograniczy. $Z$ kolei ten proces może wpłynąć na zmiany narodów i państw. Społeczności zamieszkujące strefy pogranicza, a więc nadgraniczne wspólnoty i kultury, mogą wiele wnieść do rozwoju kultury narodowej pod kątem otwartości na inne kultury. To właśnie społeczności nadgraniczne najbardziej doświadczają korzyści z tytułu otwartości granic. To one bardzo często stykają się z różnymi ponadnarodowymi strukturami, takimi jak np. euroregiony, czy regiony wchodzące w skład różnych ponadnarodowych czy międzynarodowych związków.

Nasuwa się zatem refleksja, że w warunkach procesu globalizacji następuje powolny zanik granic państwa. To rodzi $\mathrm{z}$ kolei pytanie, czy $\mathrm{w}$ warunkach zaniku 
istotnych funkcji granicy możemy mówić zarówno o przetrwaniu instytucji państwa, jak również tożsamości narodowej? Zatem pytanie o przyszłość granic państwa jest pytaniem o przyszłość państwa narodowego. W toczących się debatach nad perspektywami funkcjonowania państwa narodowego zwraca się uwagę na takie zagrożenia, jak ponadnarodowe korporacje, ponadnarodowe struktury integracyjne, globalizację kultury i społeczeństwa, a także spodziewany zanik dążeń imperialnych państw oraz innych tego rodzaju narodowych wyzwań (tamże). Procesy integracyjne, których szczególnym przykładem jest Unia Europejska sprawiają, że zasadny wydaje się pogląd, iż państwo narodowe będzie tracić swój polityczny i ekonomiczny wymiar suwerenności na rzecz struktur i instytucji ponadnarodowych. Proces zaniku granic wewnętrznych w Unii Europejskiej sprawia, że słuszne mogą wydawać się poglądy, twierdzące, że państwo narodowe ulega, co prawda przekształcaniu, jednak dyskusyjne pozostaje to, czy prowadzi to nieuchronnie do zaniku instytucji państwa. Można w tym względzie wyrazić pogląd, że w warunkach postępującej integracji państw, państwa narodowe przechodzą pewien cykl życiowy, który $\mathrm{z}$ jednej strony powoduje obumieranie pewnych funkcji związanych z tradycyjnym postrzeganiem suwerenności, z drugiej jednak strony sprawia, że państwo podlega pewnej rekonfiguracji i dostosowuje się do zmian $\mathrm{w}$ środowisku międzynarodowym. To państwo poprzez akt narodowej woli uczestniczy $\mathrm{w}$ procesie integracji, którego następstwem jest zrzeczenie się określonego zakresu suwerenności terytorialnej, na rzecz podmiotu ponadnarodowego, realizującego interesy całej wspólnoty.

Państwo narodowe i jego granice wymagają zatem szczególnej percepcji w ramach postępującej globalizacji i procesów integracyjnych. W tych warunkach granice narodowe nie mogą już dłużej pełnić funkcji bariery, a więc skutecznie chronić terytorium państwa. We współczesnych państwach, w obrębie ich społeczeństw w coraz większym stopniu dominuje świadomość, że w warunkach globalizacji nie można już dłużej problemów politycznych, ekonomicznych, społecznych czy też ekologicznych skutecznie rozwiązywać tylko w obrębie wyznaczonego granicami terytorium państwowego. Można sądzić, że współczesne państwo narodowe jest z jednej strony zbyt duże, aby wyłącznie skupić się na potrzebach i interesach środowisk lokalnych, a z drugiej strony zbyt małe, aby rozwiązywać problemy wykraczające poza jego terytorium (tamże: 207).

Przyszłość państwa narodowego należy zawsze wiązać $\mathrm{z}$ tożsamością narodową. Pojawia się $w$ tym miejscu pytanie, czy w warunkach zaniku pewnych funkcji granic prowadzących do osłabienia rangi państwa narodowego, osłabieniu ulegnie również tożsamość jego narodu? Odpowiedź na to pytanie wymaga uwzględnienia niezwykle ważnego atrybutu państwa - władzy państwowej. Zatem nasuwa się kolejne pytanie, czy w warunkach osłabienia państwa narodowego, osłabieniu ulegnie również władza państwowa?

Władzę państwową można zawsze postrzegać $\mathrm{w}$ obrębie terytorium państwa, jednak punktem, z którego można zauważać zarówno wewnętrzny jak i zewnętrzny wymiar państwa, są granice państwowe. W ramach otwartości granic coraz większa liczba ludzi kontaktuje się ze sobą ponad granicami międzypaństwowymi. Jako turyści, handlowcy, studenci, żołnierze pogranicznicy, ale także jako uchodźcy, migranci oraz przemytnicy, stworzyli oni nowy wymiar wspólnoty - innej niż ta narodowa - wspólnoty transnarodowej. W warunkach istnienia tej nowej wspólnoty granice narodowe stały się strefami przygranicznymi, które rozszerzają się w wymiarze granicy-strefy, co może z kolei powodować $w$ ich ramach zmiany w poczuciu tożsamości. W tych warunkach mieszkańcy strefy pogranicza, owe wspólnoty transnarodowe, stają się nowym wyzwaniem dla współczesnego państwa narodowego. 


\section{Literatura:}

Adeyoyin, F.A. (1989). Methodology of the Multi-disciplinary Problem. W: A. I. Asiwaju, P.O Adeniyi (red.), Borderlands in Africa. Lagos: Univeristy of Lagos Press.

Agnew, J.A. (2001a). National boundaries and Europe's borders. W: Reinventing geopolitics: Geographies of modern statehood. Heidelberg: Institute of Geography, University of Heidelberg.

Agnew, J.A. (2001b). Territoriality and political identity in Europe. W: M. Berezin, M. Schain (eds), Europe without borders: Remapping territory, citizenship and identity in a transnational age. Baltimore: The Johns Hopkins University Press.

Ancel, J. (1938). Geographie des frontieres. Paris: Gallimard.

Ancel, J. (1936). Geopolitique. Paris: Delagrave.

Anderson, M. (1996). Frontiers: Territory and State Formation in the Modern World. Oxford: Polity.

Balawajder, G. (2003). Granica polsko-czeska w kontekście integracji europejskiej. Różne aspekty ewolucji funkcji granicy. W: B. Kozera, M. Lis (red.), Ślask Opawski i Opolski w kierunku standardów europejskich, Opole: Wydawnictwo Uniwersytetu Opolskiego.

Balawajder, G. (2006). Granice państw w obszarze Unii Europejskiej. W: S.M. Grochalski (red.), Obywatel w Unii Europejskiej. Opole: Wydawnictwo Uniwersytetu Opolskiego.

Balawajder, G. (2010). Ewolucja funkcji granic a przyszłość państwa narodowego.

W: S. M. Grochalski (red.), Ewolucja instytucji granicy we współczesnej Europie. Opole:

Wydawnictwo Uniwersytetu Opolskiego.

Balawajder, G. (2010a). Zanik czy nowe funkcje granicy w Unii Europejskiej. W: S. M. Grochalski (red.), Ewolucja instytucji granicy we współczesnej Europie. Opole: Wydawnictwo Uniwersytetu Opolskiego.

Balawajder, G. (2010b). Nowe funkcje granicy. W: M. Lis, A. Trzcielińska-Polus (red.), Colloqium Opole 2009. Od Okragłego Stołu do obalenia Muru Berlińskiego i Aksamitnej Rewolucji. PolacyNiemcy - Czesi - nowe wartości, nowe relacje. Opole: PIN-Instytut Śląski.

Barbag, J. (1987). Geografia polityczna ogólna. Warszawa: PWN.

Batten, B. (1999). Frontiers and boundaries of pre-modern Japan. Journal of Historical Geography, vol. 25.

Boggs, S.W. (1940). International Boundaries. New York: Columbia University Press.

do Amaral, I. (1994). New Reflections on the Theme of International Boundaries.

W: C. H. Schofield (red.), Global Boundaries: World Boundaries, t. 1. London: Routledge.

Donnan, H., Wilson, T.M. (2007). Granice tożsamości, narodu, państwa. Kraków: Wydawnictwo Uniwersytetu Jagiellońskiego.

Ehrlich, L. (1958). Prawo międzynarodowe. Warszawa: PWN.

Grochalski, S.M. (2010). Granica - instytucja z przeszłością i niezdefiniowana przyszłością. W:. M. Lis, A. Trzcielińska-Polus (red.), Collegium Opole 2009. Od Okragtego Stotu do obalenia Muru Berlińskiego i Aksamitnej Rewolucji. Polacy - Niemcy - Czesi-nowe wartości, nowe relacje. Opole: PIN-Instytut Śląski.

Grochalski, S.M. (2010a). Granice. Prawno-międzynarodowe regulacje. W: S.M. Grochalski (red.), Ewolucja instytucji granicy we wspótczesnej Europie. Opole: Wydawnictwo Uniwersytetu Opolskiego.

Grochalski, S.M. (2010b). Wprowadzenie do problematyki instytucji granicy państwa. Refleksje obywatela Unii Europejskiej. W: S. M. Grochalski (red.), Ewolucja instytucji granicy we wspótczesnej Europie. Opole: Wydawnictwo Uniwersytetu Opolskiego.

Hartshorne, R. (1932). Geographic and Political Boundaries in Upper Silesia. Annals of the Association of American Geographers, vol.23.

Hartshorne, R. (1936). Suggestions on the terminology of political boundaries. Annals of the Association of American Geographers, vol 26 (1).

Heffner, K. (2010). Granica - rozwój instytucji (definicje, etymologia, typologia).

W:. S. M. Grochalski (red.), Ewolucja instytucji granicy we współczesnej Europie. Opole:

Wydawnictwo Uniwersytetu Opolskiego. 
Jagielski, A. (1995). Pogranicze polsko-czeskie jako problem badawczy. W: K. Heffner, W. Drobek (red.), Strefa pograniczna Polska-Czechy. Procesy transformacji i rozwoju, Opole: PIN-Instytut Śląski. Jarczyński, M. (2002). Funkcje granic w integrującej się Europie. Biuletyn Geograficzny, nr. 1. Jędrzejczak, D. (1997). Antropogeografia polska XIX i XX w. Warszawa: WGiSR UW.

Kałuski, S. (1998). Granice polityczne w problematyce geografii regionalnej. Rocznik NaukowoDydaktyczny WSP w Krakowie.

Klafkowski, A. (1996). Prawo międzynarodowe publiczne. Warszawa.

Martinez, O.J. (1994). The Dynamic of Border Interaction. W: C. H. Schofield (red.), Global Boundaries: World Boundaries, t. 1. London: Routledge.

O’Dowd, L., Wilson, T.M. (1996). Frontiers of sovereignty in the new Europe. W: L. O'Dowd, T.M. Wilson (red.), Borders, Nations and State: Frontiers of Sovereignty in the New Europe. Aldershot: Brookfield.

Otok, S. (2006). Geografia polityczna. Warszawa: Wydawnictwo Naukowe PWN.

Paasi, A. (1998). Boundaries as Social Process: Territoriality In the Word of Folks. Geopolitics, vol.3.

Pounds, N.J.G. (1936). Political Geography. New York: McGraw-Hill.

Pounds, N.J.G. (1951). The Origin of the Idea of natural Frontiers In France. Annals of the Association of American Geographers, vol. 41, no 2.

Prescott, I.R.V. (1987). Political Frontiers and Boundaries. London: Allen \& Unwin.

Rajman, J. (1993). Problematyka demograficzna i osadnicza w badaniach regionów przygranicznych Polski. W: J. Kitowski, Z. Zioło (red.), Czynniki i bariery rozwoju regionów przygranicznych. Rzeszów: Wyd. UMCS.

Reynolds, D.R., McNutty, M. (1968). On the analysis of political boundaries as barriers; a perpetual approach. East Lakes Geographer, vol. 4.

Rykiel, Z. (1990). Koncepcje granic w badaniach geograficznych. Przeglad Geograficzny, nr 62.

Rykiel, Z. (2005). Podstawy geografii politycznej. Warszawa: Polskie Wydawnictwo Ekonomiczne.

Sanguin, A.L. (1983). L'Architecture spatiale des frontieres politiques queleques

reflections theorique a propos de l'example siusse. Regia Basiliensis. Basler Zeitschrift für Geographie, vol 24, no. 1.

Szymczak, M. (red.). (1991). Stownik Języka Polskiego, t.1. Warszawa: Państwowe Wydawnictwo Naukowe.

Walters, W. (2006). Border control. European Journal of Social Theory, vol. 9, no 2. 